\title{
Comparative Study of Mud Treating Agents
}

\author{
Oloro John. \\ Senior Lecturer \\ Delta State University \\ Abraka, Delta State \\ Nigeria
}

\begin{abstract}
The right Agents for treating Mud to achieve suitable mud properties was a problem in drilling operations, hence this study was embarked on by using different agents on fresh water drilling fluids while drilling. In this paper, mud treating agents (foreign additives and local additives) on a mud was considered and compared. Two additives (foreign and local additives) were formulated at different concentrations. From the experimental results, for the weighting agent, Barite performed better than Stibnite on mud weight. Also for the pH control additives, $\mathrm{NaOH}$ performed better than Burnt Plantain/Banana Peels. While for the viscosifier, CMC performed, while Tapioca causes a rapid increase in plastic viscosity which is undesirable. For Thinners, Trona and Lignosulphate gave same reducing effects, but Trona gave a better maintenance of pH.
\end{abstract}

Keywords:- Mud, Viscosifier, Drilling, Thinners, Lignosulphate, Trona.

\section{INTRODUCTION}

Drilling mud additives are substances which when applied to the mud it improves its properties and there are different kinds of additives that are added to meet the operational requirements of a particular formation, is very necessary to rightly select additives for each mud to enhance and control for effective drilling of a well rises, hence this study was embarked on[1].

\section{A. Classification of Drilling Mud}

The working of drilling system is enhanced by the application of drilling mud. There are three major types of muds used in drilling operations, which are water based drilling mud, oil based drilling mud, and pneumatic (air, mist, foam, gas) drilling mud Johannes F [2], [3].

Water Based Mud consists 90-95\% of fresh water, salt or sea water and several dissolved substances [4]. The water based drilling fluid is grouped as follow [5].Fresh water mud is a mud having fresh water a liquid phase and with a $\mathrm{pH}$ between 7.0 and 11.0 .
Salt water muds have more than $9,000 \mathrm{mg} / \mathrm{L}$ of chloride. They may be further group base on the quantity of salt present and/or the source of makeup water. Water based drilling fluids have been proofed to be more cost effective and to be more environmental friendly than other drilling fluids as the base material itself is just water which doesn't affect the environment[6].

Oil Based Mud, these muds are available from several sources and are the oil mud containing 1-4\% water. They have been formulated for situations where water-based mud (WBM) were found inadequate. The base fluid can also be petroleum or a petroleum product such as diesel oil and mineral oil, vegetable oil [7].Some uses of oil mud are[5];

- Drilling deep, hot holes.

- Protecting producing formations.

- Drilling water soluble formations.

- Preventing differential pressure sticking.

Oil mud is highly used where high mud weight is needed and high temperature are expected. In holes where high-density water-based mud undergo degradation from high temperatures, This type of mud have been successfully used and have presented no problems even at temperatures in excess of $400^{\circ} \mathrm{F}$ [8].

Air/Gas Mud, the third class of drilling fluids comprises gas, aerated muds (classical muds with Nitrogen) or aqueous foams. These drilling fluids are generally used for unconsolidated and/or fractured formations.

Controlled drilling rate tests in various rocks have proven that air or gas is a faster drilling fluid than water or oil.Air mud is mostly used in low permeability and porosity reservoir intervals where oil or water is not expected to be encountered during drilling [9].

\section{B. Drilling Mud Properties}

To have a better control over the drilling mud system, a more meaningful monitoring strategy of the mud properties is important. The mud program is not the same for every well. In fact, in the process of drilling a well, the composition of the mud 
can be altered for variations in formation properties and mechanical factors that affect the drilling rate to be deal with. The basically, mud properties that are usually monitored during drilling include:

- Rheology

- Density

- Fluid Loss

- Other properties

\section{- Rheology}

Rheology is the study of the deformation and flow of matter. It concerned with the application of shear stress and shear rate relationship of drilling fluids. Rheological properties are used to design and evaluate the rig circulating systems and to assess the functionality of the mud system. The rheology of the mud determines the behavior of the mud and is characterized by: viscosity, plastic viscosity, yield value and gel strength [10].

\section{- Viscosity}

This is the resistance offered by a fluid to flow. This phenomenon is due to attraction between molecules of a liquid [11].The greater this resistance, the greater the viscosity. Highly viscose or thick muds are more likely to hold formation chip on bottom than low viscosity mud reducing the penetration rate Newtonian fluids, such as water, which exhibit linear follow characteristics, have a true viscosity that can be stated by a single term. Non- Newtonian fluids, including drilling mud, exhibit nonlinear flow characteristics and require more than a single viscosity term to define their visions behavior. Viscosity of a drilling mud depends on the following[5]:

1. Size, shape and number of solid particles per volume.

2. Viscosity and the base liquid.

3. Inter particle forces and.

4. Degree of emulsification of oil in water or water in oil and stability of emulsion.

The drilling mud viscosity can be expressed as either relative or absolute measurements. The relative measurements are the funnel viscosity and the apparent viscosity. Quantitative values of the non-Newtonian characteristics namely: The Plastic viscosity (PV), Yield value (YV) and Gel strength.

\section{- $\quad$ Plastic Viscosity}

The plastic viscosity is an internal resistance to fluid flow which is caused by the quantity, type and size of solids present in a given fluid. Additions of barite, and presence of chemical contaminants will increase the plastic viscosity while dilution with water, effective use of solids control equipment and flow line flocculation to remove fine size solids will lower the $\mathrm{PV}[12]$.

\section{- $\quad$ Yield Value}

The yield value (YV) is the resistance to initial flow.. This resistance is due to electrical charges located on or close to the surface of the particles.A very good control of the $\mathrm{YV}$ at an optimum level will depend on the effective control of the drilled solids.

\section{- Gel Strength}

This is the determination of the ability of a colloid to form gels. Gel strength is usually reported in $1 \mathrm{~b} / 100 \mathrm{sq} \mathrm{ft}$. The gel strength is needed to suspend the drilled cuttings and weighting materials during connections or trips when circulation of mud is stopped.

\section{- Density}

Density of drilling mud is defined as weight per unit volume. The unit is expressed as pounds per gallon (lb/gal). Density of mud is an important property which is controlled during drilling operation. In order to stop formation fluids to flow into the wellbore and to seal the wellbore with a thin, low-permeability filter cake; the density of drilling fluid must exceed the pore pressure of the formation[13]: . However, the mud column density should not be high enough to cause formation fracture. Weighting agents can be used to increase mud density to desired value using high specific gravity solid, such as barite, hematite, galena, calcium carbonate, and limonite [14].

\section{- $\quad$ Fluid-Loss}

Loss of drilling fluid is defined as the quantity of the drilling fluid that passes into the formation through the filter cake formed during drilling. It is usually prevented or minimized by mixing the mud with additives.

- $\quad$ Drilling Fluid Additives

Drilling mud additives are added to mud to improve its performance by changing its properties and composition particularly when the driller would like the mud to carry out specific function(s) to optimize the drilling operation. Many mud additives exist some performing more than one function, but only a few would be discussed subsequently.

\section{- Weighting Agents}

Weighting agents are high specific gravity substances that are added to the drilling mud to increase its density[15], [13].

- Barite

Barite is also used as a weighting agent used in drilling to preventing blowouts. Barite has API specific gravity of 4.2 - 4.5, which makes it possible to increase mud weight up to $21 \mathrm{lb} / \mathrm{gal}$ [16]

\section{- $\quad$ Stibnite (Tiro)}

Stibnite is a sulfide mineral found in low temperature hydrothermal veins and hot springs deposits. Stibnite is found associated with quartz, calcite, gold and other sulfide mineral. It is locally called Tiro.

\section{- Viscosifiers}

Viscosifiers are very important substance that help to to improve the gel strength [17]. 
Bentonite clay as well as natural polymers such as cellulose and starch is examples of Viscosifier[18].

\section{- Carboxymethyl Cellulose Sodium (CMC)}

Carboxymethyl cellulose (CMC) has been used as a viscosifier and fluid loss reducer in water based fluids and is reliable in drilling mud application [19], [20].CMC has the ability to maintain flow properties under high temperature and high pressure conditions in the presence of bentonite clay as a result of interaction between the two substances[21].

\section{- Tapioca}

Tapioca is a starch extracted from cassava root (Manihot esculenta). Although tapioca is a staple food for millions of people in the tropical countries.

- $\quad$ Alkalinity, pH Control Additives

$\mathrm{A} \mathrm{pH}$ is a value representing the hydrogen ion concentration in a liquid. $\mathrm{pH}$ indicates acidity or alkalinity of a drilling fluid. Normal drilling fluid $\mathrm{pH}$ will range between (9.5 to 10.5); higher values are not common [22]. A pH could be maintained at its correct value by treating the mud for $\mathrm{CO}_{2}$ contamination either with Caustic Soda or burnt banana or plantain peels. A calibrated $\mathrm{pH}$ meter is used to measure accurately the $\mathrm{pH}$ of a substance [23].

- Banana / plantain peels

Banana and plantain belong to the family of Musaceaae which are one of the most important fruit in the world market.The abundance of plantain and banana peels could generate ash derived alkali solution as alternative to inorganic alkali, such as $\mathrm{NaOH}$ and $\mathrm{KOH}[24]$.

- Deflocculants (Thinners)

Mud thinners or dispersants reduce viscosity by breaking the attachment of clay plates through the edges and face. Organic thinners are good for higher temperature [25].

\section{- Trona (Akanwu)}

Akanwu(in Igbo Language) also known as kanwan, kaun, kawe and potash in other parts of Nigeria (and elsewhere it is known as kanwe in Ghana and magadi in East Africa) is a naturally occurring alkaline rock salt with varying mineral compositions depending on where it is mined from. It has been described as a mineral, containing mostly sodium and carbonate. Though reported as relatively non-toxic to humans and livestock[26].

\section{MATERIALS AND APPARATUS}

In performing the experiment the under listed laboratory apparatus and materials were employed.

\section{A. Materials}

The following materials were used Bentonite clay, Carboxymethyl cellulose (CMC), Barite, Caustic Soda $(\mathrm{NaOH})$,
Lignosulphonate, burnt plantain and banana peel, Trona, Stibnite and Tapioca.

\section{B. Apparatus}

The equipments used for the research experiments include Mud Balance, $\mathrm{pH}$ Meter, Mini hand crusher, Viscometer, Multimixers and cups, Spatulas and stirrers, Conical and flat bottom flask and Beakers.

\section{EXPERIMENTAL PROCEDURES}

\section{A. Drilling Mud Preparation}

Mid-viscous water based mud was prepared for the purpose of this experiment illustrated in Table1.0 below; 21g (gram) of bentonite was measured with $350 \mathrm{ml}$ measuring cylinder meeting the API standard for a mid-viscous drilling mud.

\begin{tabular}{|l|l|l|}
\hline Mud & $\begin{array}{l}\text { Bentonite } \\
\text { concentration }(\mathbf{g})\end{array}$ & $\begin{array}{l}\text { Water } \\
(\mathbf{m l})\end{array}$ \\
\hline $\begin{array}{l}\text { Low volume } \\
\text { mud }\end{array}$ & 17.5 & 350 \\
\hline Mid viscous mud & 21 & 350 \\
\hline $\begin{array}{l}\text { High viscous } \\
\text { mud }\end{array}$ & 24.5 & 350 \\
\hline
\end{tabular}

Table 1: Water Based Drilling Mud Formation

\section{Experiment 1:}

Sample collection and preparation of Stibnite(Tiro)

Stibnite(Tiro) lumps of about 920 - 1200 grams obtained from a local market in in Oleh, Isoko South L.G.A of Delta State, it was dried by a convention solar dryer so as to remove moist. It was futher crushed to fine powder with the crusher the crushed AK-P sieved with a 200 micron sieve to obtain a fine talc size powder. The sieved Tiro powder was properly packaged and labeled, ready for use by taking successive incremental weight portion, and added to the mud sample

\section{B. Effect of Weighting Agents on A Fresh Water Drilling Fluid}

Experimental Procedure:

$24.5 \mathrm{~g}$ of high viscous bentonite clay was measured out using Weighting Balance (see Figure 2. Weighting Balance)

- These quantities were added in $350 \mathrm{ml}$ of fresh water and were mixed using the multi-mixer(see Figure 4 Mud Mixer). The mixture was agitated until the clay was thoroughly mixed to form a homogenous drilling mud.

- Varying weights of 5g, 10g, 15g, 20g, 25g and 30gof Barite were added to the fresh mud samples.

- Varying weights of $5 \mathrm{~g}, 10 \mathrm{~g}, 15 \mathrm{~g}, 20 \mathrm{~g}, 25 \mathrm{~g}$ and $30 \mathrm{gof}$ Stibnite (Tiro) as local weighting agents were added to the fresh mud samples.

- $\quad$ Before beginning, the mud balance (see figure .1) base was approximately leveled and was calibrated (calibration mark 
on scale for fresh water, $8.33 \mathrm{lb} / \mathrm{gal} / \mathrm{gal}$ or $1.0 \mathrm{~S} . \mathrm{G}$.$) , and$ made sure that the cup was clean and dry.

- The lid from the mud cup was removed and filled to overflow with the mud sample to be tested. The mud cup was briskly on the side to remove trapped air bubbles; the lid was replaced immediately on the mud cup and rotated until it was firmly sealed. It was ensured that the mud sample was filled and some mud squeezed out from the vent in the hole.

- Exterior of the mud balance was cleaned properly

- The knife on the fulcrum was set and the sliding weight was moved along the graduated arm until the cup and arm are balanced.

- The density of the mud at the left-hand edge of the sliding weight was read and measured in $\mathrm{lb} / \mathrm{gal}, \mathrm{lb} / \mathrm{ft} 3, \mathrm{SG}$, or $\mathrm{psi} / 1,000 \mathrm{ft}$ of depth.

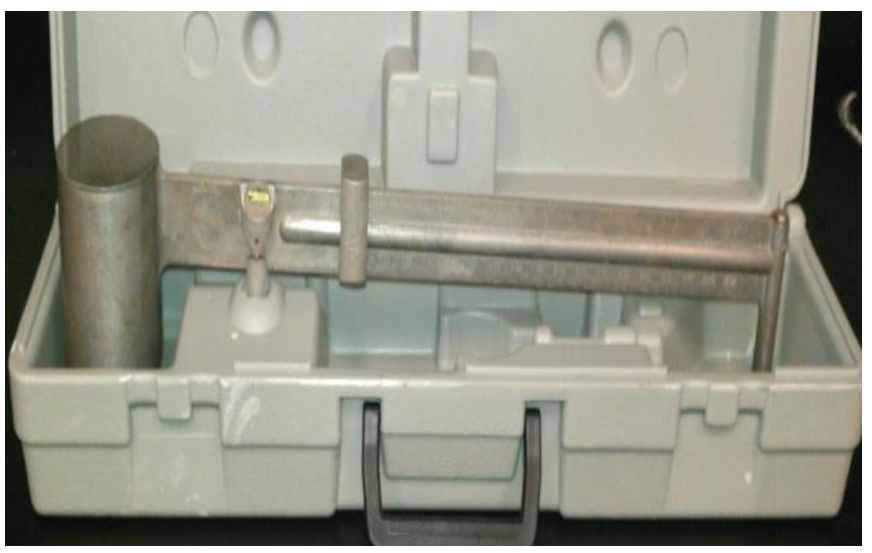

Figure 1. Mud Balance

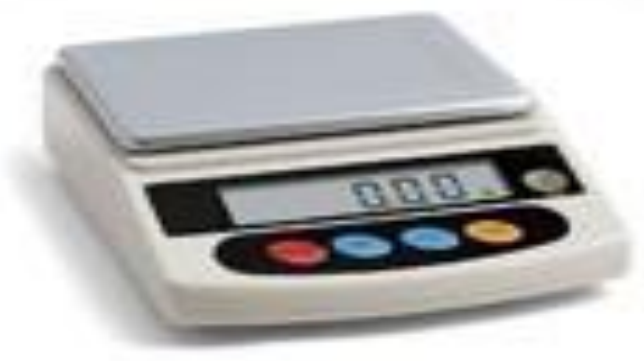

Figure 2. Weighting Balance

Experiment 2:

Sample collection and preparation of burnt Plantain/Banana Peels

The fresh Plantain and Banana peels were collected from Effurun, Uvwie L.G.A, Delta-State, Nigeria. The Plantain and Banana peels were dried separately in an oven at $100^{\circ} \mathrm{C}$ for two days to constant weight. The dried peels were placed in an open "combustion pan" and heated till the peels ignited. The ignition temperature, which was presumably very high, could not be measured with a mercury-in-glass thermometer. A metallic rod with a wooden handle was used to turn the burning peels, thus ensuring uniform combustion; the burnt peel was grinded and sieved with a set of standard mesh sieve of 200microns.

\section{Effects of $P^{H}$ Control Additives on A Fresh Water Drilling Fluid}

Experimental Procedure:

- $24.5 \mathrm{~g}$ of high viscous bentonite clay was measured out using triple beam balance. These quantities were added in $350 \mathrm{ml}$ of fresh water and were mixed using the multi-mixer. The mixture was agitated until the clay was thoroughly mixed to form a homogenous drilling mud.

- Varying weights of $5 \mathrm{~g}, 10 \mathrm{~g}, 15 \mathrm{~g}, 20 \mathrm{~g}, 25 \mathrm{~g}$ and $30 \mathrm{gof}$ Caustic soda were added to the fresh mud samples.

- Varying weights of 5g, 10g, 15g, 20g, 25g and 30g of Burnt Plantain/Banana Peel as a local Alkalinity control additives were added to the fresh mud samples.

- $\quad$ The $\mathrm{pH}$ meter (see Figure $3.0 \mathrm{pH}$ Meter) was turned on and standardized according to detailed directions.

- The electrode tips were washed properly under a stream of running water and were gently wiped dry with a clean piece of cloth.

- Electrode protective cap was removed, the electrode tip and the temperature probe was inserted or submerged into the prepared Mud Sample to be tested.

- $\quad$ Stirred gently and waited for the stability symbol

- After stability, readings were taken and recorded and after use, the electrode was rinsed with clean water and replaced with electrode protective cap.

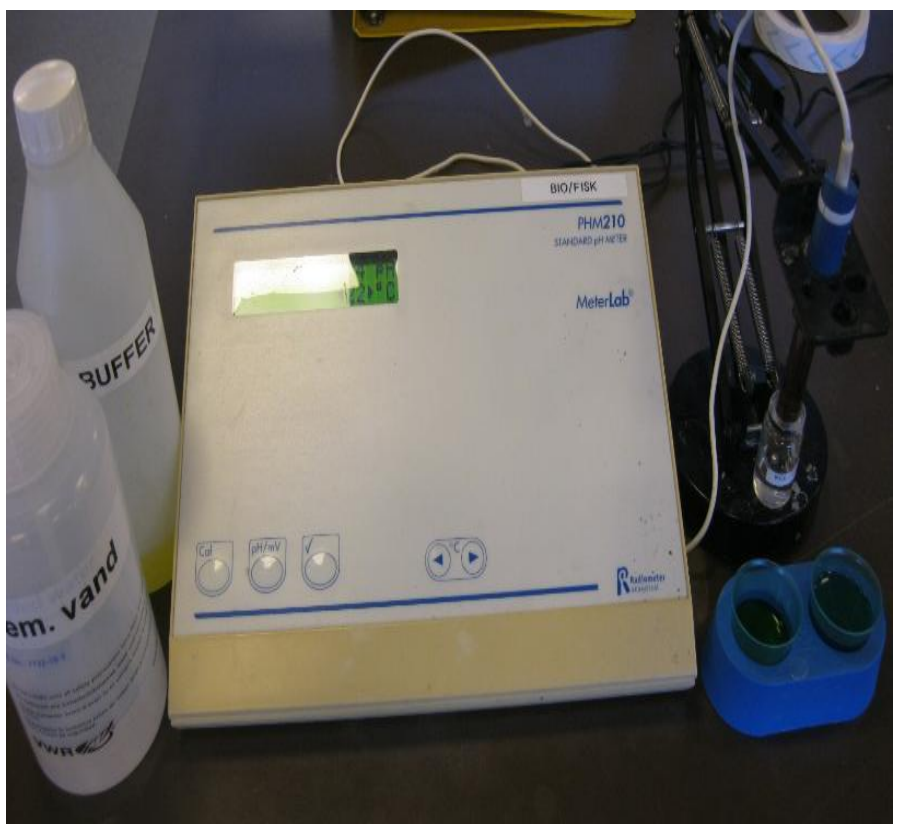

Figure 3. pH Meter 


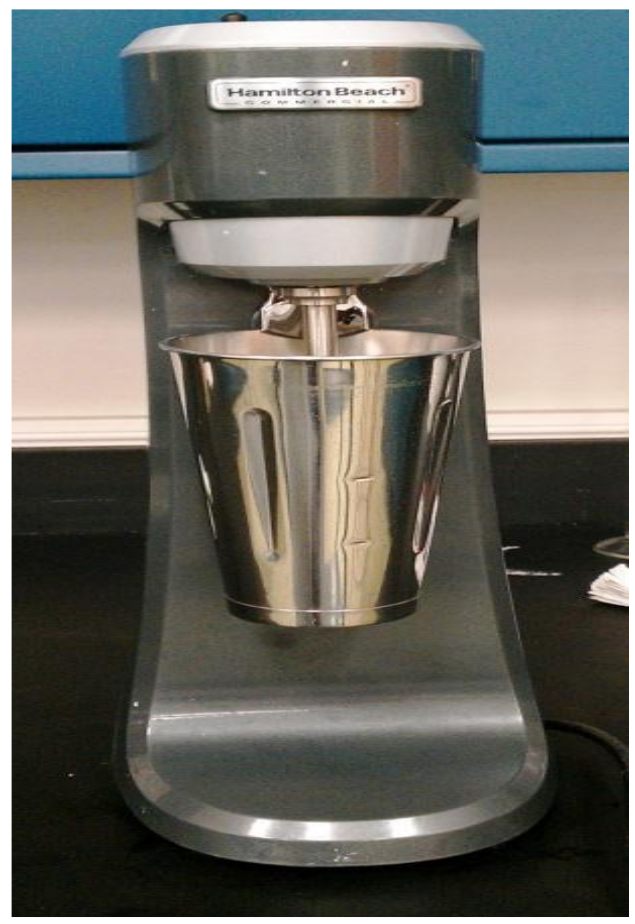

Figure 4. Mud Mixer

\section{Experiment 3}

Sample collection and preparation of Tapioca

$100 \mathrm{~g}$ of process tapioca from Warri, Delta state, Nigeria which has been processed via a natural convention solar dryer as against the open-air uncontrolled sun drying which is commonly used so as to avoid contamination via rain, dirt, dust, rodents etc. This $100 \mathrm{~g}$ of processed Tapioca is then grounded with the aid of a clean hand mill, until powdery form is obtained.

\section{Effects of Viscosifiers on A Fresh Water Drilling Fluid}

Experimental Procedure:

To obtain the 300 RPM and 600 RPM viscosity reading using a viscometer (see Figure 5 Fann Viscometer for the mud sample the following procedures was taken;

- $21 \mathrm{~g}$ of mid viscous bentonite clay was measured out using triple beam balance. These quantities were added in $350 \mathrm{ml}$ of fresh water and were mixed using the multi-mixer. The mixture was agitated until the clay was thoroughly mixed to form a homogenous drilling mud.

- The agitated mud sample was placed in the cup, tilted back into the upper housing of the rheometer, the cup was located under the sleeve (the pins on the bottom of the cup fit into the holes in the base plate), and the upper housing was lowered to its normal position.

- The knurled knob was turn between the rear support posts to raise or lower the rotor sleeve until it was immersed in the sample to the scribed line.
- The sample was stirred for about 5 minutes at 600 RPM, and then the best rpm desired was selected.

- The dial readings was waited to stabilized (the time depends on the mud characteristics).

- The dial readings and RPM were recorded.

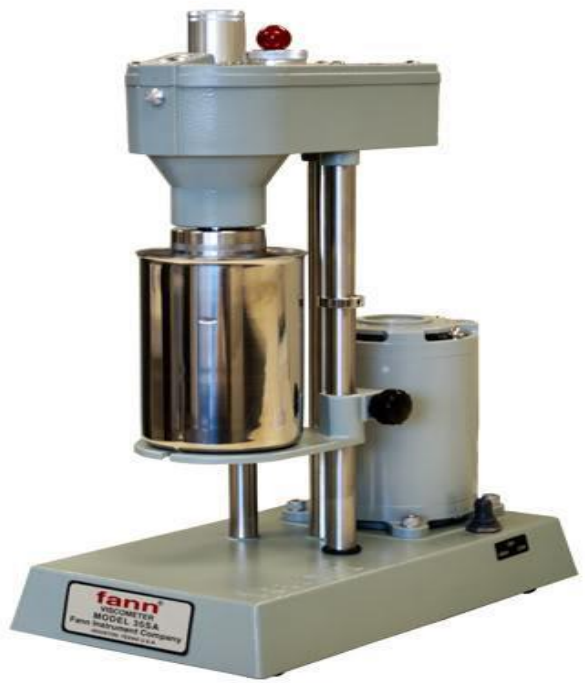

Figure 5 Fann Viscometer

Experiment 4

Sample collection and preparation of Trona (Akanwu)

Trona (Akanwu) lumps of about 920 - 1200 grams obtained from a local market in in Oleh, Isoko South L.G.A of Delta State, were crushed to fine powder with the crusher the crushed AK-P sieved with a 200 micron sieve to obtain a fine talc size powder. The sieved Trona powder was properly packaged and labeled, ready for use by taking successive incremental weight portion, and adding to the mud sample to increased level of mud $\mathrm{pH}$ impartation.

\section{E. Effects of Deflocculants (Thinners) on A Fresh Water Drilling Fluid}

Experimental Procedure:

- $21 \mathrm{~g}$ of bentonite clay was measured out using triple beam balance. These quantities were added in $350 \mathrm{ml}$ of fresh water and were mixed using the multi-mixer. The mixture was agitated until the clay was thoroughly mixed to form a homogenous drilling mud.

- Physical properties of the mud were carried out to obtain the average density, $\mathrm{pH}$, gel strength and viscosity at different speeds of viscometer.

- Various granulated weights of $2.5 \mathrm{~g}, 5 \mathrm{~g}, 7.5 \mathrm{~g}$ and $10 \mathrm{~g}$ of Trona, as local thinners, were added to fresh samples of mud and corresponding properties of the mud were measured as in the case of weighting material. 
- Various weights of $2.5 \mathrm{~g}, 5 \mathrm{~g}, 7.5 \mathrm{~g}$ and $10 \mathrm{~g}$ of lignosulphate, as thinners, were added to fresh samples of mud and corresponding mud properties were measured just like that of potash.

- Measured results were compared for the Trona and thelignosuphate.

\section{RESULTS AND DISCUSSION}

The readings of the mud weight determined using the mud balance and were recorded and tabulated in Table 2.0 below;

\begin{tabular}{|l|l|l|l|l|}
\hline $\begin{array}{l}\text { Weight of } \\
\text { Additive } \\
\text { (g) }\end{array}$ & $\begin{array}{l}\text { Stibnite } \\
\text { Mud } \\
\text { Weight } \\
\text { (ppg) }\end{array}$ & $\begin{array}{l}\text { Stibnite } \\
\mathbf{P}^{\mathbf{H}}\end{array}$ & $\begin{array}{l}\text { Barite Mud } \\
\text { weight } \mathbf{p p g})\end{array}$ & $\begin{array}{l}\text { Barite } \\
\mathbf{P}^{\mathbf{H}}\end{array}$ \\
\hline 0 & 8.49 & 10.27 & 8.49 & 10.27 \\
\hline 5 & 8.57 & 10.19 & 8.57 & 10.49 \\
\hline 10 & 8.64 & 9.98 & 8.71 & 10.34 \\
\hline 15 & 8.70 & 9.72 & 8.82 & 10.30 \\
\hline 20 & 8.76 & 9.35 & 8.89 & 10.25 \\
\hline 25 & 8.82 & 8.76 & 8.94 & 10.22 \\
\hline 30 & 8.87 & 8.14 & 8.96 & 10.20 \\
\hline
\end{tabular}

Table 2: Effect of Weighting Additives on Mud Density and $\mathrm{pH}$

Table 2. shows the results of the effect of weighting agent on Mud Density and pH. From the results on the mud weight, it was obtained that Barite used as a weighting agent gave an increase in mud density over Stibnite. Barite increases the mud density from $8.49 \mathrm{ppg}$ to $8.96 \mathrm{ppg}$ while Stibnite gave an increase from $8.49 \mathrm{ppg}$ to $8.87 \mathrm{ppg}$. From Table1, the results obtained on the mud $\mathrm{pH}$ of the weighting agent, it shows that Barite gave a better performance on the mud $\mathrm{pH}$ than Stibnite. Barite maintained the mud $\mathrm{pH}$ from the range of 10.27 to 10.20 while Stibnite caused a reduction in the mud $\mathrm{pH}$ from 10.27 to 8.14 .

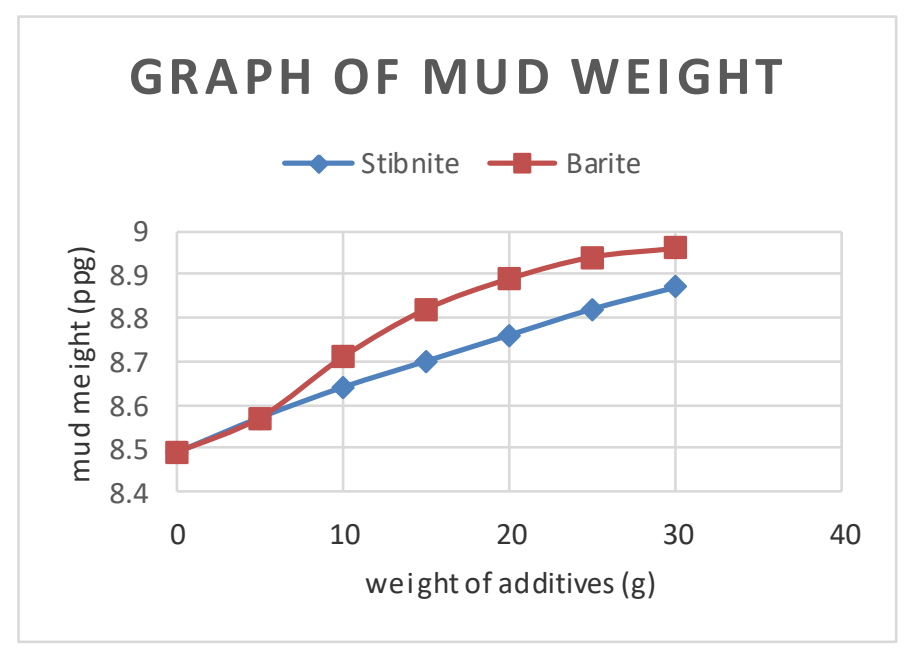

Figure 6 Graph Showing Mud Weight for Stibnite and Barite
Figure 6 shows the graph of the mud weight using Barite and Stibnite as the weighting agents. From the graph it was observed that increasing the weight of the Barite gave an increase in the mud weight, while increasing the weight of Stibnite causes an increase in the mud weight slightly below Barite. Therefore, Barite gave a better performance and control on the mud weight than Stibnite, Furthermore; modification of Stibnite can also increase the mud weight.

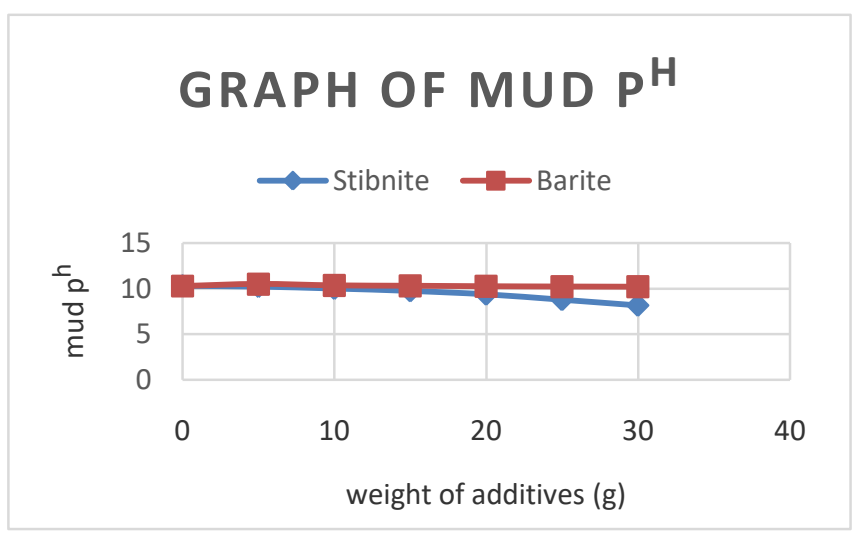

Figure 7 Graph Showing Mud $\mathrm{P}^{\mathrm{H}}$ for Stibnite and Barite

Figure 7 shows the graph of mud $\mathrm{pH}$ using Stibnite and Barite as the weighting agents. From the graph it was observed that increasing the weight of Barite gave a better maintenance in the mud $\mathrm{pH}$, while increasing the weight Stibnite results to reduction in the mud $\mathrm{pH}$, which might make the drilling mud to be corrosive and acidic. Therefore, from the graph Barite gave a better control and maintenance on the mud $\mathrm{P}^{\mathrm{H}}$ than Stibnite, which tends to favor Barite over Stibnite.

\section{A. Results on Effects of Viscosifiers on A Fresh Water Drilling Fluid}

For the viscosity determination as described in the experiments from the previous readings were determined using the viscometer and the corresponding varying viscosity of the additives readings gotten were also recorded in centipoise (cp) in Table 3. below;

\begin{tabular}{|c|c|c|c|c|}
\hline $\begin{array}{l}\text { Additives } \\
\text { conc. }\end{array}$ & $\begin{array}{l}\text { O300 } \\
\text { Tapioca } \\
\text { (cp) }\end{array}$ & $\begin{array}{l}\text { Ө300 CMC } \\
\text { (cp) }\end{array}$ & $\begin{array}{l}\mathbf{\Theta 6 0 0} \\
\text { Tapioca } \\
\text { (cp) }\end{array}$ & $\begin{array}{l}\text { O600 } \\
\text { CMC } \\
\text { (cp) }\end{array}$ \\
\hline 0.0 & 12.2 & 12.2 & 18.2 & 18.2 \\
\hline 0.2 & 15.2 & 17.7 & 24.2 & 25.7 \\
\hline 0.4 & 18.2 & 26.2 & 27.7 & 34.2 \\
\hline 0.6 & 20.2 & 33.2 & 30.2 & 42.7 \\
\hline 0.8 & 20.7 & 40.2 & 31.7 & 48.2 \\
\hline
\end{tabular}

Table 3: Viscosity Readings for Tapioca and CMC at $300 \mathrm{rpm}$ and 600rpm 
Rheological Calculations

Mathematically; Plastic viscosity, Apparent viscosity and Yield point can be calculated using the following expressions;

1. Plastic viscosity (in centipoise-cp):

Plastic Viscosity $(\mu p)=600$ RPM reading - 300 RPM Reading
2. Apparent Viscosity (in centipoise-cp):

Apparent Viscosity $(\mu \mathrm{a})=600$ RPM Reading $/ 2$

3. Yield Point (in $\mathrm{lb} / 100 \mathrm{ft} 2$ ):

Yield Point $($ Y.P $)=300$ RPM Reading - Plastic Viscosity

\begin{tabular}{|c|c|c|c|c|c|c|c|c|c|c|}
\hline $\begin{array}{l}\text { Additives } \\
\text { Conc. }\end{array}$ & $\begin{array}{l}\text { O300 } \\
\text { Tapioca } \\
\text { (cp) }\end{array}$ & 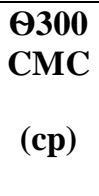 & $\begin{array}{c}\Theta 600 \\
\text { Tapioca } \\
\text { (cp) }\end{array}$ & $\begin{array}{l}\text { O600 } \\
\text { CMC } \\
\text { (cp) }\end{array}$ & $\begin{array}{c}\text { AV } \\
\text { Tapioca } \\
\text { (cp) }\end{array}$ & $\begin{array}{c}\text { AV } \\
\text { CMC } \\
\text { (cp) }\end{array}$ & $\begin{array}{c}\text { PV } \\
\text { Tapioca } \\
\text { (cp) }\end{array}$ & $\begin{array}{c}\text { PV } \\
\text { CMC } \\
\text { (cp) }\end{array}$ & $\begin{array}{l}\text { YP } \\
\text { Tapioca } \\
\text { (cp) }\end{array}$ & $\begin{array}{l}\text { YP } \\
\text { CMC } \\
\text { (cp) }\end{array}$ \\
\hline 0.0 & 12.2 & 12.2 & 18.2 & 18.2 & 9.10 & 9.10 & 6.0 & 6.0 & 6.2 & 6.2 \\
\hline 0.2 & 15.2 & 17.7 & 24.2 & 25.7 & 12.10 & 12.85 & 9.0 & 8.0 & 6.2 & 9.7 \\
\hline 0.4 & 18.2 & 26.2 & 27.7 & 34.2 & 13.85 & 17.10 & 9.5 & 8.0 & 8.7 & 18.2 \\
\hline 0.6 & 20.2 & 33.2 & 30.2 & 42.7 & 15.10 & 21.35 & 10.0 & 9.5 & 10.2 & 23.7 \\
\hline 0.8 & 20.7 & 40.2 & 31.7 & 48.2 & 15.85 & 24.10 & 11.0 & 8.0 & 9.7 & 32.2 \\
\hline
\end{tabular}

Table 4: Apparent, Plastic viscosities and yield point of CMC and Tapioca

Table 4, shows the results of apparent and plastic viscosities and yield point of CMC and Tapioca. It was observed that increasing weights of CMC gave a better increase in yield point than Tapioca; CMC gave a rapid increase in yield point from $6.2 \mathrm{cp}$ to $32.2 \mathrm{cp}$ while Tapioca gave a slight increase from $6.2 \mathrm{cp}$ to $9.2 \mathrm{cp}$. From Table 3, It was also observed that Tapioca causes a rapid increase in plastic viscosity than $\mathrm{CMC}$ which is undesirable, Tapioca increases the plastic viscosity from $6.0 \mathrm{cp}$ to $11.0 \mathrm{cp}$ while CMC gave a slight increment from $6.0 \mathrm{cp}$ to $8.0 \mathrm{cp}$.

\section{GRAPH OF YIELD POINT}

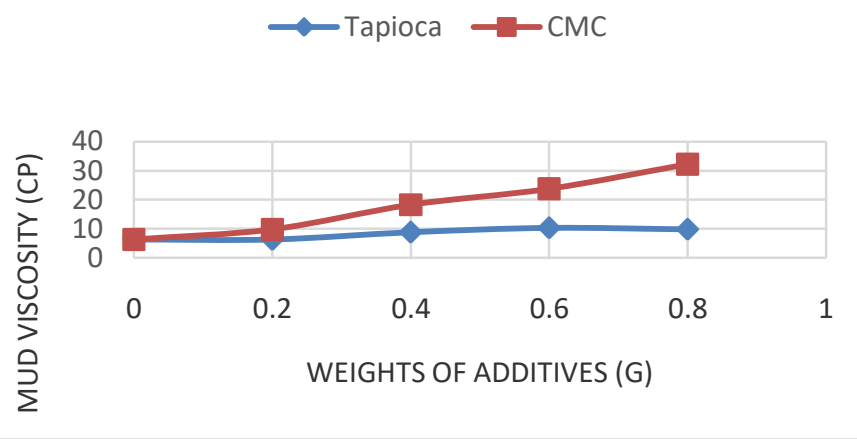

Figure 8. Graph of Yield Point for Tapioca and C.M.C
Figure 8 shows the graph of yield point for Tapioca and C.M.C used as a viscosifier on the drilling mud. From the graph, it was observed that increasing varying weights of CMC gave a better yield point than Tapioca, The yield point is used as a measure to evaluate the ability of the drilling mud to lift cutting out of the annulus to the surface. Therefore, CMC gave a better control and performance to remove cuttings and cleaning of the wellbore than Tapioca.

\section{PLASTIC VISCOSITY}

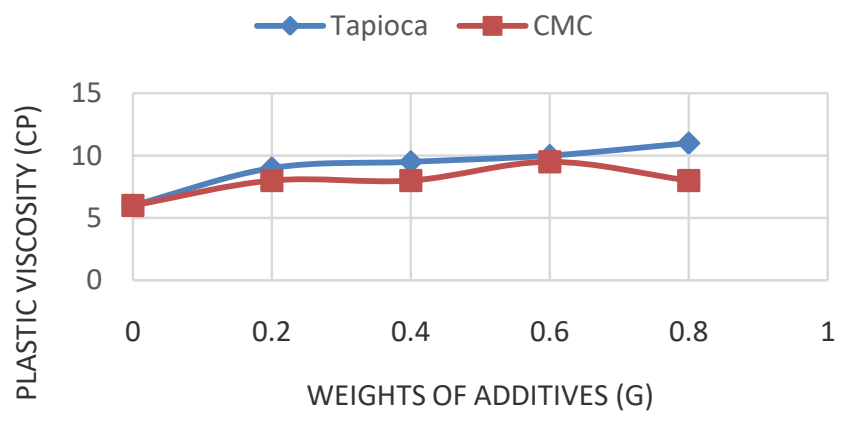

Figure 9. Graph showing Plastic viscosity Tapioca and CMC 
Figure 9 shows the graph of plastic viscosity of Tapioca and CMC used as a viscosifier on the drilling mud. From the graph, it was observed that as the varying weight of Tapioca increases, it gave a rapid increase in plastic viscosity than CMC which is undesirable; The plastic viscosity is used to measure the internal resistance to flow due to amount, type and size of solids in the drilling mud. Therefore, Tapioca used as a viscosifier causes an accumulation of drilled solids and presence of chemical contaminants than CMC.

\section{B. Results on Effects of $P^{h}$ Control Additives on A Fresh Water Drilling Fluid}

On the $\mathrm{pH}$ determination and the experiments described in the previous chapter, the readings for the $\mathrm{pH}$ determination were determined using the $\mathrm{pH}$ meter with the corresponding varying weights of the additives, the readings were recorded and tabulated in Table 5. below;

\begin{tabular}{|l|l|l|l|}
\hline $\begin{array}{l}\text { Weights of } \\
\text { Additives } \\
\text { (g) }\end{array}$ & $\begin{array}{l}\text { Plantain ash } \\
\text { Mud pH }\end{array}$ & $\begin{array}{l}\text { Banana ash } \\
\text { Mud Ph }\end{array}$ & $\begin{array}{l}\text { NaOH } \\
\text { Mud } \\
\text { pH }\end{array}$ \\
\hline 0.2 & 7.8 & 7.8 & 11.8 \\
\hline 0.4 & 8.8 & 8.3 & 12.3 \\
\hline 0.6 & 9.8 & 8.8 & 12.8 \\
\hline 0.8 & 10.3 & 9.8 & 13.3 \\
\hline 1.0 & 11.8 & 10.8 & 13.8 \\
\hline 1.2 & 12.3 & 11.3 & 13.8 \\
\hline 1.4 & 12.8 & 11.8 & 13.8 \\
\hline
\end{tabular}

Table 5: Results showing Mud pH for Plantain/Banana Ash and $\mathrm{NaOH}$

Table 5, shows the results of mud $\mathrm{pH}$ for Burnt Plantain ash, Banana ash and $\mathrm{NaOH}$. The results obtained shows that $\mathrm{NaOH}$ gave a better performance in the increment of the mud $\mathrm{pH}$ from 7.8 to 13.8 , while burnt plantain and banana peel were able to increase the mud $\mathrm{pH}$ from 7.8 , to 12.8 to 11.8 respectively.

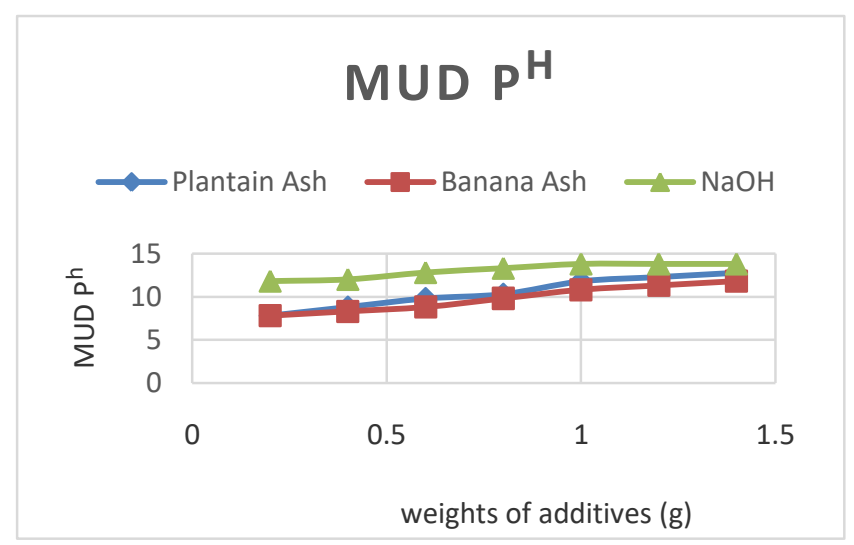

Figure 10 Graph showing mud $\mathrm{P}^{\mathrm{H}}$ for Plantain/Banana Ash and $\mathrm{NaOH}$
Figure 10, shows the graph of mud $\mathrm{pH}$ for Burnt Plantain/Banana peel and $\mathrm{NaOH}$. From the graph, it was also observed that increasing the weight of $\mathrm{NaOH}$ gave a better performance and increment in the mud $\mathrm{pH}$ than Burnt Plantain/Banana peels. However, it was established that burnt banana/plantain peels also had great effect on the mud $\mathrm{pH}$, but the Plantain peels were more effective than Banana peels.Further modification on Burnt Plantain/Banana peel can improve mud $\mathrm{pH}$.

C. Results on Effects of Deflocculants (Thinners) on A Fresh Water Drilling Fluid

For determination of the thinners, relationship between viscosity and gel strength were determined. Experimental procedures for mud weight, the viscosity and the $\mathrm{pH}$ as described in the experiment from the previous chapter, were recorded and the readings were tabulated below;

\begin{tabular}{|c|c|c|c|c|}
\hline & \multicolumn{2}{|l|}{ Lignosulphate } & \multicolumn{2}{l|}{ Trona } \\
\hline $\begin{array}{c}\text { Weights of } \\
\text { Additives (g) }\end{array}$ & $\begin{array}{c}\text { Mud } \\
\text { weights } \\
\text { (ppg) }\end{array}$ & $\mathbf{p H}$ & $\begin{array}{c}\text { Mud } \\
\text { weights } \\
\text { (ppg) }\end{array}$ & Ph \\
\hline 0.0 & 8.48 & $\begin{array}{c}10.2 \\
6\end{array}$ & 8.48 & 10.26 \\
\hline 2.5 & 8.31 & 8.96 & 8.31 & 9.87 \\
\hline 5.0 & 8.11 & 8.97 & 8.11 & 9.86 \\
\hline 7.5 & 7.96 & 8.96 & 7.86 & 9.85 \\
\hline 10.0 & 7.86 & 8.98 & 6.91 & 9.83 \\
\hline
\end{tabular}

Table 6: Mud Density and pH Variation with Weight of Thinner Additives

Table 6, shows the results for the mud density and $\mathrm{pH}$ of Lignosulphonate of the Thinner additives (Lignosulphate and Trona). The results obtained shows that Trona causes a rapid reduction in mud weight than Lignosulphate. From the table, it was also observed that Trona gave a better maintenance of the mud $\mathrm{pH}$ than Lignosulphate

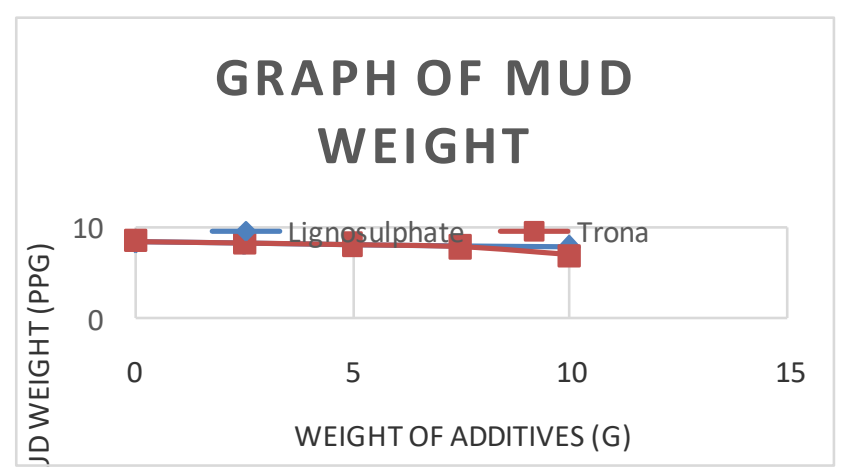

Figure 11 Graph Showing mud weight for Lignosulphate and Trona 
Figure 11, shows the graph of mud weight of Lignosulphate and Trona. From the graph it was observed that increasing the weight of Trona causes a reduction effect on weight of mud than Lignosulphate. However, there is need to reduce the mud density due to the possibility of lost circulation as a result of over-weight mud, especially when abnormal low pressure zone is encountered during drilling. Therefore, Trona will be a more effective thinner in the reduction of the mud density than Lignosulphate.

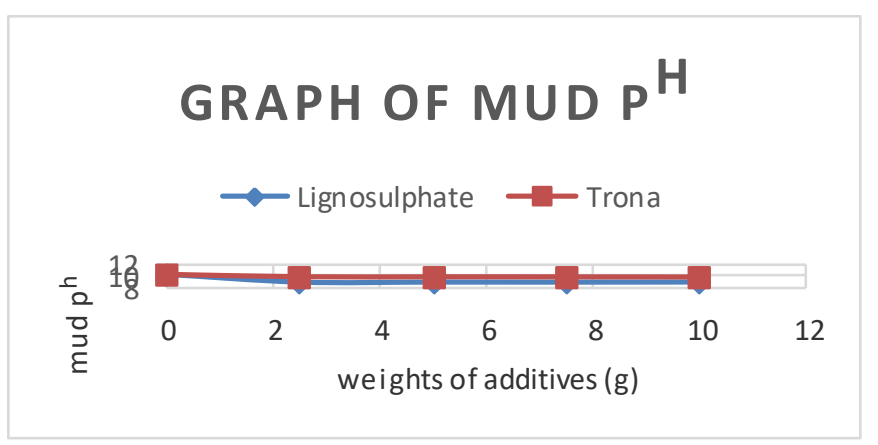

Figure 12, shows the graph of the mud $\mathrm{pH}$ for Lignosulphate and Trona. From the graph, it was observed that increasing weight of Trona gave a better maintenance of the mud $\mathrm{pH}$, while Lignosulphate causes a rapid reduction in the mud $\mathrm{pH}$. However, this rapid reduction in mud $\mathrm{pH}$ caused by Lignosulphate makes the drilling mud to become more acidic and affects the performance of the mud. Therefore, Trona used as a Thinner gave a better performance on mud $\mathrm{pH}$ than Lignosulphate.

Figure 12 Graph Showing mud $\mathrm{P}^{\mathrm{H}}$ for Lignosulphate and Trona

\begin{tabular}{|c|c|c|c|c|c|c|c|c|c|c|}
\hline $\begin{array}{l}\text { Weight } \\
\text { of } \\
\text { Additiv } \\
\text { es } \\
\text { (g) }\end{array}$ & $\begin{array}{l}\text { O600Lignosulp } \\
\text { hate }\end{array}$ & $\begin{array}{l}\text { O60 } \\
\text { 0 } \\
\text { Tro } \\
\text { na }\end{array}$ & $\begin{array}{l}\text { O300 } \\
\text { Lignosulph } \\
\text { ate }\end{array}$ & $\begin{array}{l}\text { O30 } \\
\text { 0 } \\
\text { Tro } \\
\text { na }\end{array}$ & $\begin{array}{l}\text { AV } \\
\text { Lignosulpho } \\
\text { nate }\end{array}$ & $\begin{array}{l}\text { AV } \\
\text { Tro } \\
\text { na }\end{array}$ & $\begin{array}{l}\text { PV } \\
\text { Lignosulpho } \\
\text { nate }\end{array}$ & $\begin{array}{l}\text { PV } \\
\text { Tro } \\
\text { na }\end{array}$ & $\begin{array}{l}\text { YP } \\
\text { Lignosulpho } \\
\text { nate }\end{array}$ & $\begin{array}{l}\text { YP } \\
\text { Tro } \\
\text { na }\end{array}$ \\
\hline 0 & 13.6 & 13.6 & 9.80 & 9.80 & 6.7 & 6.7 & 3.6 & 3.6 & 6.0 & 6.0 \\
\hline 2.5 & 13.5 & 13.3 & 9.3 & 9.60 & 6.65 & 6.55 & 4.0 & 3.5 & 5.1 & 5.9 \\
\hline 5 & 13.1 & 12.3 & 8.80 & 8.80 & 6.45 & 6.05 & 4.1 & 3.3 & 4.5 & 5.3 \\
\hline 7.5 & 12.4 & 11.5 & 8.3 & 8.3 & 6.1 & 5.65 & 3.90 & 3.0 & 4.2 & 5.1 \\
\hline 10 & 11.3 & 10.9 & 6.80 & 7.8 & 5.55 & 5.35 & 4.3 & 2.9 & 2.3 & 4.7 \\
\hline
\end{tabular}

Table 7: Viscosity Readings for Lignosulphateand Potash Additive

Table 7, shows the viscosity reading of Lignosulphate and Trona used as thinners in the drilling mud. The results obtained shows that at 300RPM Lignosulphate have more reduction effect on the mud viscosity than Trona; while at 600RPM Trona causes a rapid reduction in mud viscosity than Lignosulphate.

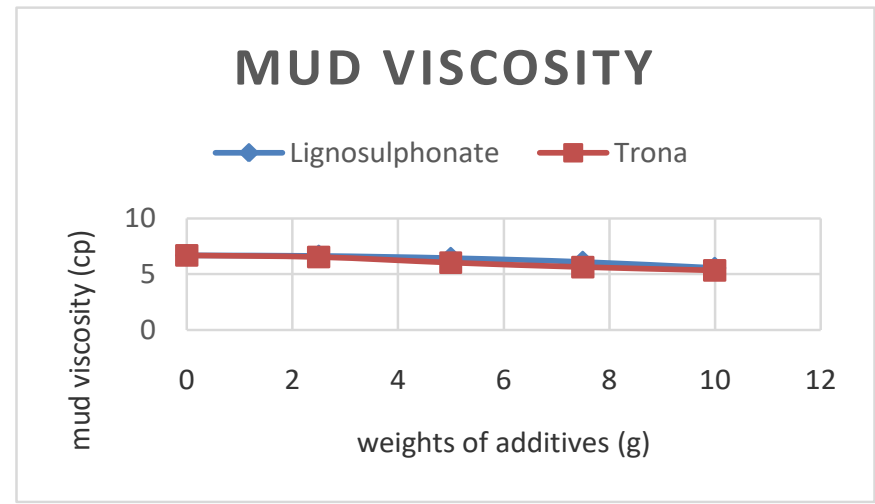

Figure 13 Graph Showing mud Viscosity for Lignosulphate and Trona 
Figure 13, shows the graph of mud viscosity of Lignosulphate and Trona used as Deflocculants (thinners). From the graph, it was observed that both Lignosulphonate and Trona has reduction effects on the mud viscosity, but increasing the weights of Trona has more reducing effects on the mud viscosity than Lignosulphonate.

\section{FINDINGS}

During the cause of the experiment, the following findings were obtained when comparing the effects of foreign mud treating agent with the local mud treating agent on a fresh water drilling fluid, and the findings are as follows;

- Using C.M.C and Tapioca as viscosifiers on a fresh water drilling fluid, it was observed that C.M.C gave a better yield point than Tapioca, which means that C.M.C used as a viscosifier removes more drill cuttings and aids in cleaning the wellbore.

- It was also obtained that Tapioca has a higher plastic viscosity than C.M.C, which is undesirable as it causes accumulations of solids contaminants and dirt in the drilling mud.

- Using Lignosulphate and Trona as thinners on a fresh water drilling fluid, it was observed that Trona gave a better maintenance of the mud $\mathrm{pH}$, than Lignosulphate.

\section{CONCLUSION}

Based on the results obtained during the experiment carried out on the effects of these additives on fresh water drilling, the following conclusion was reached;

- Barite used as a weighting agent, gave better performance on mud weight and $\mathrm{pH}$ maintenance than Stibnite. Therefore, Stibnite should be combined with another additive that will maintain the $\mathrm{pH}$ of the mud.

- For the viscosifier, C.M.C gave a better performance on yield point than Tapioca, while Tapioca gives a high plastic viscosity than CMC which is undesirable. This indicates that Tapioca causes accumulation of drilled solids and presence of chemical contaminants than CMC.

- For the $\mathrm{pH}$ control additives, $\mathrm{NaOH}$ gave a better performance than Burnt Plantain/Banana peels, but further modifications on Burnt Plantain/Banana peels will enchance increase in mud $\mathrm{pH}$.

- Using Lignosulphate and Trona as thinners, it was observed that both additives have same reducing influence on mud weight, but Trona gave a better result in $\mathrm{pH}$ maintenance than the Lignosulphate and this gives Potash more relevance than Lignosulphate.

\section{REFERENCES}

[1]. Bourgouyne, A.T, Millhiem, K. K, Chenevert, M. E, Young, F. S. ,1991, Applied drilling engineering (Richardson, Texas, Society of Petroleum Engineers.

[2]. Johannes F., 2011, Petroleum Engineer's Guide to Oil Field Chemicals and Fluids. Gulf professional publication, an imprint of Elsevier inc., USA.1st Edition.1-785.

[3]. Ariffin S. and Amir H. (2011) "Water based mud lifting capacity improvement by multiwall carbon nanotubes additive". Journal of Petroleum and Gas Engineering Vol. 2(5), pp. 99-107.

[4]. Skalle, P., 2010. Drilling Fluid Engineering, Bookboon.

[5]. Ikeh, O.A, (2014); “Contributions Of Petroleum Drilling Mud To Environmental Pollution: Assessment Of Heavy Metals And Poly Aromatic Hydrocarbons In Oil Based Petroleum Drilling Mud" Department Of Pure And Industrial Chemistry, University Of Nigeria, Nsukka.

[6]. Neff, J.M., 2005. Composition, environmental fates, and biological effects of water based drilling muds and cuttings discharged to the marine environment: Asynthesis andannotated bibliography. Petroleum Environmental Research Forum (PERF) andAmerican Petroleum Institute.

[7]. UKOOA, 1999b. United Kingdom Offshore Oils Association. UKOOA environmental report 1999. [Last accessed2ndJuly2009].http://www.ukooa.org.issues/1999rep ort/enviro99_drill.cfm

[8]. Van Dyke K, Baker R (1998). Drilling Fluids, Mud Pumps, and Conditioning Equipment

University of Texas at Austin, Petroleum Extension Service.

[9]. Coussot, P.; Bertrand, F. and Herzhaft, B. (2004). Rheological Behaviour of Drilling muds, characterization using MRI visualization. Oil \& Gas science Technology - Rev. IFP 59(1,) 23-29.

[10]. Bourgoyne Jr., A. T., Millheim, K. K., Chenevert, M. E., \& Young Jr., F. (1986). Applied Drilling Engineering. Richardson, TX: Society of Petroleum Engineering.

[11]. Clark, E. P.,. Drilling Mud Rheology and the API recommended Measurements. Society of Petroleum Engineers, Inc., (1995).

[12]. Azar, J., \& Samuel, G. R.. Drilling Engineering. PennWell Corporation, 2007.

[13]. Darley, H. C., \& Gray, G. R. Composition and Properties of Drilling and Completion Fluids. Gulf Professional Pub., 1988.

[14]. Max R. Annis, M.V.S.,. Drilling Fluid Technology Exxon Manual, 1996.

[15]. Bourgoyne Jr., A. T., Millheim, K. K., Chenevert, M. E., \& Young Jr., F., Applied Drilling Engineering. Richardson, TX: Society of Petroleum Engineering, (1986).

[16]. Hanson, P.M., Trigg, T.K., Rachal , G., and Zamora, M . Investigation of Barite "sag" in Weighted Drilling Fluids in Highly Deviated Wells. SPE 160916-STU, International Student Paper Contest ATCE Texas, 1990 
[17]. Caenn, R., Chillingar, G.V.,. Drilling fluids: state of the art. Journal of Petroleum Science and Engineering, 1996,14. 221-230.

[18]. Neff, J.M., 2005. Composition, environmental fates, and biological effects of water based drilling muds and cuttings discharged to the marine environment: Asynthesis andannotated bibliography. Petroleum Environmental Research Forum (PERF) andAmerican Petroleum Institute.

[19]. Young, S.Y. and Mass T., Novel polymer chemistry increases shale stability, Drilling Technology, American Association of Drilling Engineers, AADE National Drilling Technical Conference, AADE 01-NC-HO-41, Houston (TX), (2001). March 27-29.

[20]. Kirk-Othmer, Kirk-Othmer Encyclopedia of Chemical Technology, Volume 9, 5th Edition.

[21]. Menezes, R.R., Marques, L.N., Campos, L.A., Ferreira, H.S., Santana, L.N.L., Neves, G.A., Useof statistical design to study the influence of CMC on the rheological properties of bentonite dispersions for water-based drilling fluids. Appl. Clay Sci., 2010.,49, 13-20.

[22]. Finger, J., and Blankenship, D., 2010: Handbook of best practices for geothermal drilling. Sandia National Laboratories, Albuquerque, NM, United States, report SAND, 2010-6048, 84 pp.

[23]. Baker Hughes INTEQ,: drilling engineering workbook. A distributed learning course . Baker Hughes INTEQ Inc. 1995.

[24]. Adebowale, O.J \& Jamiudeen K.R, "Local Content Supplements As An Alternative To Imported Corrosion Control Additives For Drilling Mud Treatment" Proceedings of The International Academic Conference for Sub-Sahara African Transformation \& Development , 2015,Vol. 3 No.4.

[25]. Hudgins CM. , Chemical usage in North Sea oil and production and exploration. Report for the Norwegian Oil Industry Environmental Committee 1991,https://en.m.wikipedia.org/wiki/Sodium_hydroxide

[26]. Emebiri, L.C. and Nwufo, M.I.. Effect of Trona (urao) on the survival and reproduction of Sitophilus zeamais and Tribolium castaneum on stored maize. Agriculture, Ecosytem and Environment, 1990,32: 69-75. 